\begin{tabular}{|c|c|}
\hline $\begin{array}{l}\text { JOURNAL OF EDUCATIONAL } \\
\text { REVIEW AND RESEARCH }\end{array}$ & $\begin{array}{l}\text { JOURNAL OF EDUCATIONAL REVIEW AND RESEARCH } \\
\text { Vol. } 1 \text { No. 2, December 2018. Page: } 80-\mathbf{8 5} \\
\text { e-ISSN: 2597-9760, p-ISSN: } 2597-9752\end{array}$ \\
\hline $\begin{array}{l}\text { (c) (i) @) This work is licen } \\
\text { a Creative Commo }\end{array}$ & $\begin{array}{l}\text { sed under } \\
\text { רs Attribution-NonCommercial } 4.0 \text { International License. }\end{array}$ \\
\hline
\end{tabular}

\title{
ANALISIS STRATEGI GURU DALAM MENANAMKAN KEMAMPUAN LITERASI SAINS SISWA SEKOLAH DASAR
}

\author{
Tandri Aisah $^{1}$, Emi Sulistri $^{2}$ \\ Pendidikan Guru Sekolah Dasar, STKIP Singkawang, Singkawang, Indonesia
} tandri.aisyah@gmail.com ${ }^{1}$,sulistriemi@gmail.com ${ }^{2}$

\begin{tabular}{ll}
\hline Keywords : & ABSTRACT \\
Strategi, literasi sains & Tujuan penulisan artikel ini adalah untuk \\
& mendeskripsikan strategi guru SD dalam \\
& menanamkan kemampuan litasi sains siswa sekolah \\
& dasar. Metode yang digunakan adalah survey. Teknik \\
& analisis yang digunakan adalah studi literatur. Hasil \\
& analisis yang dilakukan, menunjukkan bahwa strategi \\
& yang digunakan oleh guru dalam menanamkan \\
kemampuan literasi sains siswa sangat berkaitan. & Namun kebanyakan guru dalam proses pembelajaran \\
& berlangsung masih terfokus menggunakan buku. \\
& Sehingga membuat kemampuan literasi sains siswa \\
& tergolong rendah. Jadi, dapat disimpulkan bahwa \\
& dalam menanamkan kemampuan literasi sains siswa \\
& sekolah dasar guru perlu memperhatikan strategi \\
& yang akan digunakan dalam menanamkan \\
kemampuan literasi sains.
\end{tabular}

\section{INTRODUCTION}

Strategi pembelajaran merupakan rencana tindakan (rangkaian kegiatan) termasuk penggunaan metode dan pemanfaatan berbagai sumber daya/ kekuatan dalam proses pembelajaran (Sumantri, 2015 : 279). Ada beberapa istilah lain yang berkaitan dengan strategi pembelajaran, yakni pendekatan, metode, teknik, dan taktik. Gambaran kaitan tersebut dapat ditentukan bahwa sesuatu strategi pembelajaran yang diterapkan guru akan tergantung pada pendekatan yang digunakan; sedangkan bagaimana menjalankan strategi itu dapat diterapkan berbagai metode pembelajaran. Upaya menjalankan metode pembelajaran guru dapat menentukan teknik yang dianggapnya relevan dengan metode dan dalam penggunaan teknik, setiap guru memiliki teknik yang mungkin berbeda antara guru yang satu dengan yang lain.

Berdasarkan hasil laporan Trends In International Mathematics and Science Study (TIMSS) 2015 yang baru diikuti untuk siswa kelas empat sekolah dasar Indonesia memperoleh poin 397 dengan ranking 45 dari 48 negara. Data tersebut merupakan pencapaian kemampuan literasi sains negara Indonesia menurut TIMSS. Indonesia masih menduduki posisi 45 dari 48 negara, hal tersebut dapat disimpulkan bahwa kemampuan literasi sains siswa masih tergolong rendah. Hal tesebut disebabkan karena pada saat proses pembelajaran berlangsung 
guru hanya menggunkan metode yang kovensional. Selain itu, guru hanya menggunkan sumber belajar yaitu satu buku. Tak hanya itu pada saat proses pembelajaran, guru menggunkan buku pelajaran $90 \%$ dari alokasi waktu pembelajaran.

Strategi atau metode mengajar merupakan salah satu komponen yang harus ada dalam kegiatan pembelajaran karena untuk mencapai tujuan pembelajaran maupun dalam upaya membentuk kemampuan literasi sains siswa diperlukan adanya suatu metode yang efektif. Penggunaan strategi atau metode mengajar harus dapat menciptakan terjadinya interaksi antara siswa dengan siswa maupun antara siswa dengan guru sehingga proses pembelajaran dapat dilakukan secara maksimal. Strategi/metode mengajar memiliki fungsi sentral dalam pembelajaran yaitu sebagai cara untuk menamkan kemampuan literasi sains siswa.

Literasi sains adalah kemampuan pengetahuan sains, mengidentifikasi pertanyaan, dan menarik kesimpulan berdasarkan bukti-bukti dalam rangka memahami serta membuat keputusan berkenaan dengan alam dan perubahan yang dilakukan terhadap alam melalui aktivitas manusia. Menurut Norris dan Philips (Abidin, 2017:141) mengemukakan istilah literasi sains digunakan untuk beberapa aspek yang meliputi hal berikut, (1) Pengetahuan mengenai konten subtantif sain dan kemampuan untuk membedakan dari nonsains; (2) Pemahaman sains dan penerapan; (3) Pengetahuan mengenai sains itu sendiri; (4) Kebabasan dalam belajar sains; (5) Kemampuan berpikir ilmiah; (6) Kemampuan menggunakan pengetahuan sains dalam memecahkan masalah; (7) Pengetahuan yang diperlukan untuk berpatisipsai cerdas dalam isu-isu berbasis sains dan (8) Pemahaman mengenai sifat-sifat sains, termasuk hubungan dengan kebudayaan.

Berdasarkan istilah literasi sains menurut Norris dan Philips dapat disimpulkan bahwa literasi sains itu sangat penting bagi anak SD. Literasi sains tersebut bermanfaat untuk siswa dalam kehidupan sehari-hari seperti pada poin keenam, kemampuan menggunakan sains dalam memecahkan masalah. Siswa dapat memecahkan suatu masalah dengan menggunakan pengetahuan sains yang milikinya. Oleh karena itu, perlu adanya penanaman literasi sains dalam pembelajaran melalui pengkaitan materi dengan konteks kehidupan sehari-hari.

Penanaman literasi sains perlu dilakukan dengan harapan memberikan wadah bagi siswa untuk mempelajari diri sendiri, lingkungan sekitar, dan mengaplikasikan pengetahuan untuk memecahkan permasalahan bertujuan memenuhi kebutuhan sehari-hari melalui proses penemuan. Siswa yang memiliki literasi sains yang baik, diharapkan memiliki kompetensi sikap, kompetensi pengetahuan, dan kompetensi keterampilan dengan berfikir dan bertindak produktif dan kreatif untuk mempersiapkan menhadapi tantangan abad 21.

\section{METHOD}

Jenis penelitian ini adalah penelitian deskriptif. Adapun metode yang digunakan dalam penelitian ini adalah survey. Sampel yang digunakan sebanyak 4 buah. Data diperoleh dari menelaah artikel, jurnal, prosiding maupun sumber-sumber yang lain yang berkaitan dengan penelitian kemudian disimpulkan. Pengolahan dan analisis data dilakukan secara kualitatif dan kumulatif dengan penjabaran deskriptif. 


\section{RESULTS AND DISCUSSIONS}

Pembelajaran sains merupakan salah satu cara penanaman konsep sederhana pada anak. Pengenalan sains pada anak ditekankan pada proses dari pada produk. Sains juga melatih anak menggunakan lima inderanya untuk mengeksplosasi terhadap berbagai kejadian maupun benda. Namun kenyataannya masih banyak guru belum mampu menerapkan pembelajaran sains sederhana untuk menanamkan konsep pada anak. Guru kebanyakan hanya memberi lembar kerja siswa untuk kegiatan pembelajaran. Hal ini menyebabkan pembelajaran yang dilakukan pada anak kurang menarik dan sulit untuk diingat (Eny Nur Aisyah, starategi pembelajaran sains untuk anak pra sekolah dan seklah dasar. Universitas Negeri Malang). Negara Indonesia, literasi sains dalam pembelajaran IPA sebagian besar masih terbatas pada materi buku ajar atau teks saja dari pada melakukan pembelajaran langsung.

Menurut Stake \& Easly (dalam jurnal Reny Kristyowati, Agung Purwanto, 2019 hal 184 ) menyatakan bahwa guru dalam proses pembelajaran menggunakan buku pelajaran $90 \%$ dari alokasi waktu pembelajaran. Hal tersebut mengakibatkan kemampuan literasi sains tergolong rendah. Pembelajaran tersebut lebih berpusat pada guru dan metode yang digunakan oleh guru juga tidak jauh dari metode ceramah sains. Selain itu pendekatan yang dilakukan oleh guru adalah pendekatan expository, dimana guru yang lebih aktif sedangkan siswa menjadi pasif. Hal ini menyebabkan pelajaran sains terasa berat dan membosankan yang pada akhirnya peserta didik kurang memahami pembelajaran.

Pengetahuan dan penerapan literasi sains yang hanya mengandalkan buku ajar atau teks belum sepenuhnya menyentuh jiwa peserta didik. Metode ceramah yang digunakan juga kurang relevan yang menyebabkan peserta didik hanya menjadi pendengar yang pasif. Apabila hal itu dilanjutkan membuat peserta didik tidak akan dapat bersaing di era abad 21.

Penelitian yang dilakukan oleh Balqis Fauzatul Rohmah tahun 2017 dengan judul "Strategi Guru dalam Membina Literasi Sains di Madrasah Ibtidaiyah", hasil penelitian bahwa sebagai berikut :

\begin{tabular}{rlrl}
\hline No. & Nama sekolah & $\begin{array}{l}\text { Strategi } \\
\text { Pembelajaran }\end{array}$ & $\begin{array}{l}\text { Hasil strategi pembelajaran } \\
\text { yang digunakan oleh guru }\end{array}$ \\
\hline $\begin{array}{l}\text { 1. } \\
\text { MI Sabilul Muhtadi }\end{array}$ & Kooperatif & $\begin{array}{l}\text { Meningkatkan rasa percaya } \\
\text { diri siswa serta lebih kritis }\end{array}$ \\
\hline $\begin{array}{l}\text { 2. } \\
\text { MI Miftahul Huda } \\
\text { Banjarejo }\end{array}$ & Inkuiri & $\begin{array}{l}\text { Membentuk karakter literasi } \\
\text { sains siswa }\end{array}$ \\
\hline 3. & $\begin{array}{l}\text { MI Al-Wathoniyah } \\
\text { Tegalrejo }\end{array}$ & Ekspositori & $\begin{array}{l}\text { Penyampaian materi pelajaran } \\
\text { seacara optimal }\end{array}$ \\
\hline 4. & MI Darussalam Blimbing & Kontekstual & Memotivasi siswa \\
\hline
\end{tabular}

Berdasarkan penelitian yang dilakukan oleh Balqis Fauzatul Rohmah tahun 2017 dengan judul Strategi Guru dalam Membina Literasi Sains di Madrasah Ibtidaiyah, strategi pembelajaran kooperatif yang digunakan oleh sekolah MI Sabilul Muhtadi Pakisrejo membuat rasa percaya diri siswa serta lebih kritis membuat kemampuan literasi sains siswa meningkat. Strategi pembelajaran inkuiri yang digunakan oleh sekolah MI Miftahul Huda Banjarejo membuat terbentuknya karakter literasi sains siswa, pembentukkan karakteristik literasi sains siswa disesuaikan dengan tujuan pembelajaran dan kompetensi dasar sains. Strategi pembelajaran ekspositori yang digunakan oleh MI Al-Wathoniyah Tegalrejo membuat guru dalam menyampaikan materi dapat tersampaikan secara optimal walaupun tidak menggunakan media pembelajaran atau alat bantu dalam proses pembelajaran 
berlangsung, sehigga dalam menanmkan kemmapuan literasi sains dapat disampaikan secara optimal dengan menggunkan strategi pembelajaran ekspositori. Strategi pembelajaran kontekstual yang digunakan oleh MI Darussalam Blimbing dapat membantu memotivasi siswa, sehingga dalam menanamkan kemampuan literasi sains siswa dengan menggunakan strategi pembelajaran kontekstual dapat dilakukan dengan cara memotivasi siswa.

Berdasarkan paparan diatas dapat disimpulkan bahwa strategi pembelajaran yang digunakan oleh guru dalam menanamkan kemampuan literasi sains tidak hanya menanamkan pengetahuan sains saja namun proses sains, sikap ilmiah, penanamakan nilai karakter sains, meningkatkan rasa percaya diri agar lebih berpikir kritis, memotivasi siswa dan dalam penyampaian materi pelajaran tersampaikan secara optimal.

Menurut Krisyowati Reni dan Agung Purwanto, 2019 dengan judul "Pembelajaran Literasi Sains Melalui Pemanfaatan Lingkungan" memaparkan bahwa rendahnya kemamapuan literasi sains disebabkan oleh pemilihan sumber belajar yang digunakan oleh guru. Pembelajaran literasi sains melalui pemnafaatan lingkungan seabagai sumber belajar memberi dampak pada kemampuan literasi sains siswa meningkat. Melalui pemanfaatan lingkungan sebagai sumber belajar, peserta didik diajak untuk memahami konsep, menerapkan konsep, memecahkan masalah hingga menyimpulkan suatu permasalahan dengan melibatkan lingkungan sekitar yang dekat dengan peserta didik. Selain itu peserta didik lebih mudah memahami pelajaran dan menghindari kejenuhan.

Menurut Yuyu Yilianti 2017 dengan judul “ Literasi Sanis dalam Pembelajaran IPA" Pembelajaran yang menitik beratkan kepada pencapaian literasi sains adalah pembelajaran yang sesuai dengan hakitat pembelajaran sains yang mana pembelajaran tidak hanya sekedar menekankan pada hafalan pengetauan saja melainkan berorientasi pada proses dan ketercapaian sikap ilmiah. Oleh karena itu, pembelajaran sebaiknya dilaksanakan secara inkuiri ilmiah (Scientific inquiry) untuk menumbuhkan kemampuan berpikir, bekerja dan bersikap ilmiah serta mengkomunikasikannya sebagai aspek penting kecakapan hidup. Pemberian pengalaman langsung dengan cara inkuiri kritis ini, diharapkan dapat membantu peserta didik untuk memperoleh pemahaman yang lebih mendalam tentang alam sekitar. Sedangkan, keaktifan atau proses kerja inkuiri dalam mengikuti proses pembelajaran diperlukan agar pengetahuan yang diperoleh peserta didik dapat lebih bertahan lama. Proses kerja inkuiri ini dilakukan dalam kerja kolaboratif sehingga siswa akan mampu berkolaborasi sekaligus akan terampil berkomunikasi. Selain itu kebermaknan pembelajaran sains juga dapat dicapai dengan cara mengaitkan konsep yang dipelajari peserta didik dengan kehidupan sehari-hari hal ini dikarenakan keberhasilan pembelajaran dalam mewujudkan visinya ditunjukkan apabila peserta didik memahami apa yang dipelajari serta dapat mengaplikasikannya dalam menyelesaikan berbagai permasalahan pada kehidupan seharihari.

Monalisa Gherardini, 2016 dengan judul "Pengaruh metode pembelajaran dan kemampuan berpikir kritis terhadap kemampuan literasi sains" sebagai berikut :

1. Kemampuan literasi sains pada kelompok siswa yang diberi metode pembelajaran CPS lebih tinggi dibandingkan kemampuan literasi sains pada kelompok siswa yang diberi metode pembelajaran Problem Posing.

2. Terdapat pengaruh interaksi antara metode pembelajaran dan kemampuan berpikir kritis terhadap kemampuan literasi sains. 
3. Bagisiswa yang memiliki kemampuan berpikir kritis tinggi, Kemampuan literasi sains antara kelompok yang diajarkan metode pembelajaran CPS lebih tinggi dibandingkan kelompok siswa yang diajar menggunakan metode pembelajaran Problem Posing.

4. Bagi siswa yang memiliki kemampuan berpikir kritis rendah, kemampuan literasi sains antara kelompok yang diajar menggunakan metode pembelajaran CPS lebih rendah dibandingkan kelompok siswa yang diberi metode pembelajaran Problem Posing.

Berdasarkan hasil penelitian yang dilakukan oleh Monalisa Gherardini dapat disimpulkan bahwa Kemampuan literasi sains pada kelompok siswa yang diberi metode pembelajaran CPS lebih tinggi dibandingkan kemampuan literasi sains pada kelompok siswa yang diberi metode pembelajaran Problem Posing.

Berdasarkan keempat paparan diatas dapat disimpulkan bahwa, strategi pembelajaran yang digunakan oleh guru dapat mempengaruhi penanaman kemampuan literasi sains pada siswa sekolah dasar. Setiap strategi yang digunakan oleh guru memiliki dampak yang berbeda dalam menanamkan kemampuan literasi sains pada siswa. Ada yang berdampak pada pembentukkan karakter sains, memotivasi siswa, penyampaian materi yang ptimal, meningkatkan rasa percaya diri, menghilangkan kejenuhan dan lainlain. Namun, pada hakikatnya strategi yang digunakan oleh untuk menanamkan kemampuan literasi sains siswa sangat berkaitan erat.

\section{CONCLUSION AND SUGGESTION}

Berdasarkan penjelasan yang telah dibahas dapat disimpulkan bahwa dalam menanamkan kemampuan literasi sains siswa di Indonesia berdasarkan TIMSS masih tergolong rendah. Hal tersebut disebabkan oleh guru dalam proses pembelajaran $90 \%$ alokasi waktunya hanya menggunakan sumber belajar buku dan metode yang konvensional. Masalah tersebut harus diatasi dengan memilih strategi yang sesuai dengan karakteristik siswa, suasana kelas dan materi yang akan disampaikan. Kemampuan Literasi merupakan hal fundamental yang harus dimiliki oleh peserta didik dalam menghadapi era global untuk dapat memenuhi kebutuhan hidup dalam berbagai situasi. Literasi sains merupakan kemampuan untuk memahami sains, mengkomunikasikan sains, serta menerapkan kemampuan sains untuk memecahkan masalah. Untuk meningkatkan kemampuan literasi sains siswa, guru juga perlu mempertimbangkan strategi pembelajaran yang sesuai dengan kondisi dan potensi siswa yang mana pada proses pembelajarannya menitik beratkan pada pemberian pengalaman langsung dan pengaplikasian hakikat sains.

\section{REFERENCES}

Abidin, Yunus, dkk. 2017. Pembelajaran Literasi. Jakarta : Bumi Aksara

Aisyah, Eny Nur. 2016. Strategi Pembelajaran Sains untuk Anak Prasekolah dan Sekolah Dasar Awal. Universitas Negeri Malang

Gherardini, Monalisa. 2016. Pengaruh metode pembelajaran dan kemampuan berpikir kritis terhadap kemampuan literasi sains. Universitas Negeri Jakarta. JURNAL PENDIDIKAN DASAR Volume 7 Edisi 2 Desember 2016

Kristyowati, Reni dan Agung Purwanto. 2019. Pembelajaran Literasi Sains Melalui Pemanfataan Lingkungan. Universitas Negeri Jakarta

Noviyanti, Erna. 2017. Pendekatan Saintifik dan Kontekstual dalam Pembelajaran Literasi 
Sains di Sekolah Dasar. Universitas Islam Sultan Agung. Prosiding Seminar Nasional

OECD. 2003. The PISA 2003 Assessment Framework. Paris: OECD

OECD. 2015. PISA 2015 Results. OECD. (http://www.businessinsider.co.id/pisa-worldwideranking-of-math-science-reading-skills-2016-12/) diakses pada tanggal 17 Oktober 2019 pukul 18.00 WIB

Rohmah, Balqis Fauzatul. 2017. Stretegi Guru dalam Membina Literasi Sains di madrasah Ibtidaiyah. Universitas Islam Negeri Maulana Malik Ibrahim Malang. Tesis (hal 127145)

Sugiyono. 2017. Metode Penelitian Pendidikan. Bandung : Alfabeta Bandung

Sumanstri, Mohamaad Syarif. 2015. Strategi Pembelajaran. Jakarta : PT Raja Grafindo Persada

Yulianti, Yuyu. 2017. Literasi Sains dalam Pembelajaran IPA. Universitas Majalengka. Jurnal cakrawala pendas. Vol 3 No 2. Edisi Juli 2017. 